\title{
POST-HARVEST RESIDUES OF NARROW-LEAVED LUPIN (Lupinus angustifolius L.) / SPRING RYE (Secale cereal L.) MIXTURES AS A SOURCE OF BIOLOGICAL NITROGEN FOR WINTER TRITICALE (Triticosecale Wittm. ex A. Camus)
}

\author{
PŁAZA, A. - GĄSIOROWSKA, B. - RZĄŻEWSKA, E. \\ Siedlce University of Natural Sciences and Humanities, Faculty of Agrobioengineering and \\ Animal Husbandry, Institute of Agriculture and Horticulture, Siedlce, Poland \\ *Corresponding author \\ e-mail: emilia.rzazewska@uph.edu.pl \\ (Received $3^{\text {rd }}$ Dec 2019; accepted 24 $4^{\text {th }}$ Mar 2020)
}

\begin{abstract}
Field research was conducted in 2010-2012 to determine the manuring value of the postharvest residues of narrow-leafed lupin (Lupinus angustifolius $\mathrm{L}$.)/spring rye (Secale cereal L.) mixtures. The following two experimental factors were investigated: I. forecrop - mixtures: narrow-leafed lupin pure stand $100 \%$, spring rye - pure stand $100 \%$, narrow-leafed lupin $75 \%$ + spring rye $25 \%$, narrowleafed lupin 50\% + spring rye 50\%, narrow-leafed lupin 25\% + spring rye $75 \%$; II. forecrop harvest date: narrow-leafed lupin flowering stage, flat green pod stage. It was inferred, based on the obtained results, that the greatest quantity of post-harvest residues wassupplied by spring rye as well as narrow-leafed lupin/spring rye mixtures containing $25+75 \%$ and $50+50 \%$ of the respective components, harvested at the stage of flat green pod of narrow-leafed lupin, the greatest nitrogen amount being supplied by narrowleafed lupin harvested at the aforementioned development stage. The highest grain yield was produced by winter triticale (Triticosecale Wittm.ex A.Camus) following an incorporation of the post-harvest residues of narrow-leafed lupin/spring rye mixture containing $50+50 \%$ of the respective components and harvested at the stage of narrow-leafed lupin flat green pod.
\end{abstract}

Keywords: forecrop, 1000 grain weight, yield, total nitrogen content

\section{Introduction}

Legume/cereal mixtures are valuable green fodder crops fed to cattle, their post-harvest residues being a source of biological nitrogen for following crop plants, cereals in particular. Also, they are more environmentally friendly than mineral nitrogen fertilisers (Jensen and Hauggard-Nielsen, 2003; Herridge et al., 2008). Compared to legume post-harvest residues, such biomass has a broader $\mathrm{C}: \mathrm{N}$ ratio, which results in its mineralisation process being slowed down. As reported by Mayer et al. (2003), Tripolskaja and Šidlauskas (2010) as well as Nemeikšiene et al. (2010), an application of legume post-harvest residues preceding winter wheat results in mineral nitrogen leaching into deeper soil strata during the autumn-winter-spring period, which is caused by rapid mineralization of such biomass. As far as the post-harvest residues of legume/cereal mixtures are concerned, the biological nitrogen is gradually released to be used by the following plant throughout the whole growing season, which prevents its leaching and protects the soil environment (Arlauskiene and Maiksteniene, 2008; Nemeikšiene et al., 2010).

Triticale is a species which has been recently introduced for cultivation purposes. A paucity of literature has been noticed pertaining to the manuring value of legume/cereal post-harvest residues for this crop plant. 
It has been assumed that an incorporation of the crop residues of narrow-leafed lupine/spring rye mixtures at the stage of narrow-leafed lupin flowering and flat green pod will make it possible to determine differences in yield performance and amount of nitrogen accumulated in winter triticale grain, and indicate which mixtures have the most beneficial effect on grain yield and amount of nitrogen accumulated in winter triticale grain.

The objective of the study was to determine the manuring value of post-harvest residues of narrow-leafed lupin/spring rye mixtures harvested at the stage of narrow-leafed lupin flowering and flat green pod, expressed in terms of grain yield and amount of biological nitrogen accumulated in winter triticale grain.

\section{Materials and Methods}

Field research was conducted in 2010-2012 at the Zawady Experimental Farm $\left(52^{\circ} 03^{\prime} 39^{\prime \prime} \mathrm{N}, 22^{\circ} 33^{\prime} 80^{\prime} \mathrm{E}\right)$ of Siedlce University of Natural Sciences and Humanities in Poland. The soil on which the experiment was set up wasStagnicLuvisol, its reaction was neutral and it contained average amounts of available phosphorus, potassium and magnesium. Humus content was $1.40 \%$. The experiment was a split-block arrangement with three replicates. The following two factors were examined: I. forecrop - mixtures: narrow-leafed lupin, pure stand $100 \%$, spring rye, pure stand $100 \%$, narrow-leafed lupin $75 \%+$ spring rye $25 \%$, narrow-leafed lupin $50 \%+$ spring rye $50 \%$, narrow-leafed lupin $25 \%+$ spring rye $75 \%$; II. harvest date: the stage of narrow-leafed lupin flowering, the stage of narrow-leafed lupin flat green pod. The following seeding rates were used: narrow-leafed lupin 260 seedsm $^{-2}$, spring rye 217 grains $\mathrm{m}^{-2}$, narrow-leafed lupin 195 seeds $\mathrm{m}^{-2}+$ spring rye 54 grains $\mathrm{m}^{-2}$, narrow-leafed lupin 130 seeds $\mathrm{m}^{-2}+$ spring rye109 grains $\mathrm{m}^{-2}$, narrow-leafed lupin $65 \mathrm{seedsm}^{-2}+$ spring rye 163 grainsm $^{-2}$. In all the study years, the mixtures were preceded by oats. Theagrotechnics of mixtures narrow-leafed lupin + spring rye are presented in the Table 1. Narrow-leafed lupin (cv. Zeus) and spring rye(cv. Bojko) seeds were planted in early April as described for factor I. The plants were harvested in late June (stage of narrow-leafed lupin flowering) and early July (stage of narrow-leafed lupin flat green pod). Following forecrop harvest, post-harvest residues of narrow-leafed lupin/oat mixtures were collected from an area of $1 \mathrm{~m}^{2}$ and to the depth of $30 \mathrm{~cm}$ in each plot in order to determine their dry matter yield. The residue dry matter was used to determine total nitrogen content (by means ofKjeldahl method).

Winter triticale cv. Borwo was sown in mid-September at the rate of 239 grains $\mathrm{m}^{-2}$. Pre-plant phosphorus and potassium applications were made at the rates adjusted to soil availability, that is $70 \mathrm{~kg}^{-1} \mathrm{P}$ and $99 \mathrm{~kg}^{-1} \mathrm{~K}$. Nitrogen fertiliser was split into two rates of 40 and $60 \mathrm{kghh}^{-1}$ applied, respectively, after the cereal resumed growth in the spring, and at the stage of stem elongation. Winter triticale was harvested in late July. Grain yield was determined in each plot and its average samples were taken to determine total nitrogen by Kjeldahl method (AOAC, 2006). Additionally, 1000 grain weight was recorded.

Analysis of variance (split-block) was performed on the data for each experimental characteristic.Means were compared using Tukey's test, at the significance level of $\mathrm{P} \leq 0.05$, when significant sources of variation had been confirmed. All the statistical calculations were performed using the authors' algorithms in MS Excel 7.0. 
Table 1. The agrotechnics of mixtures narrow-leafed lupin + spring rye in experiment 2010-2012

\begin{tabular}{|c|c|c|c|c|}
\hline \multirow{3}{*}{$\begin{array}{c}\text { Forecrop - } \\
\text { mixtures }\end{array}$} & \multicolumn{3}{|c|}{ Fertilization } & \multirow{3}{*}{ Plant protection } \\
\hline & \multicolumn{2}{|c|}{ Before sowing } & ВBCH 31-32 & \\
\hline & in autumn & \multicolumn{2}{|c|}{ in spring } & \\
\hline $\begin{array}{c}\text { Narrow-leafed } \\
\text { lupine - pure stand } \\
100 \% \\
\end{array}$ & $\begin{array}{l}35.2{\mathrm{~kg} h \mathrm{ha}^{-1} \mathrm{P}} \\
99.6 \mathrm{~kg}^{-1} \mathrm{~K}\end{array}$ & - & - & $\begin{array}{c}\text { mechanical } \\
\text { weed control } \\
\text { (harrow) }\end{array}$ \\
\hline $\begin{array}{l}\text { Spring rye - pure } \\
\text { stand } 100 \%\end{array}$ & $\begin{array}{l}35.2{\mathrm{~kg} h \mathrm{~h}^{-1} \mathrm{P}} \\
99.6 \mathrm{~kg}^{-1} \mathrm{~K}\end{array}$ & $\begin{array}{c}30 \mathrm{~kg}_{\mathrm{N}} \mathrm{ha}^{-1} \\
\mathrm{~N}\end{array}$ & $50 \mathrm{~kg}^{-1} \mathrm{~N}$ & $\begin{array}{c}\text { mechanical } \\
\text { weed control } \\
\text { (harrow) } \\
\end{array}$ \\
\hline $\begin{array}{c}\text { Narrow-leafed } \\
\text { lupine } 75 \%+\text { spring } \\
\text { rye } 25 \%\end{array}$ & $\begin{array}{l}35.2 \mathrm{kghha}^{-1} \mathrm{P} \\
99.6 \mathrm{~kg} \mathrm{ha}^{-1} \mathrm{~K}\end{array}$ & $\begin{array}{c}30 \mathrm{~kg} \mathrm{ha}^{-1} \\
\mathrm{~N}\end{array}$ & $30 \mathrm{~kg} \mathrm{ha}^{-1} \mathrm{~N}$ & $\begin{array}{c}\text { mechanical } \\
\text { weed control } \\
\text { (harrow) } \\
\end{array}$ \\
\hline $\begin{array}{c}\text { Narrow-leafed } \\
\text { lupine } 50 \%+\text { spring } \\
\text { rye } 50 \%\end{array}$ & $\begin{array}{l}35.2{\mathrm{~kg} h a^{-1} \mathrm{P}} \\
99.6 \mathrm{~kg}^{-1} \mathrm{~K}\end{array}$ & $\begin{array}{c}30 \mathrm{~kg} \mathrm{ha}^{-1} \\
\mathrm{~N}\end{array}$ & $30 \mathrm{~kg} \mathrm{ha}^{-1} \mathrm{~N}$ & $\begin{array}{c}\text { mechanical } \\
\text { weed control } \\
\text { (harrow) }\end{array}$ \\
\hline $\begin{array}{c}\text { Narrow-leafed } \\
\text { lupine } 25 \%+\text { spring } \\
\text { rye } 75 \%\end{array}$ & $\begin{array}{l}35.2{\mathrm{~kg} h \mathrm{~h}^{-1} \mathrm{P}} \mathrm{P} \\
99.6 \mathrm{~kg} \mathrm{ha}^{-1} \mathrm{~K}\end{array}$ & $\begin{array}{c}30 \mathrm{~kg}_{\mathrm{N}} \mathrm{ha}^{-1} \\
\mathrm{~N}\end{array}$ & $30 \mathrm{~kg} \mathrm{ha}^{-1} \mathrm{~N}$ & $\begin{array}{c}\text { mechanical } \\
\text { weed control } \\
\text { (harrow) }\end{array}$ \\
\hline
\end{tabular}

\section{Results}

\section{Dry matter yield of the post-harvest residues of narrow-leafed lupin/spring rye mixtures}

The dry matter yield of the post-harvest residues of narrow-leafed lupin/spring rye mixtures was significantly affected by the experimental factors and their interaction (Table 2).

Table 2. Dry matter quantity of forecrop post-harvest residues (averaged across 2010-2011), teha

\begin{tabular}{|c|c|c|c|}
\hline \multirow[b]{2}{*}{ Forecrop - mixtures (I) } & \multicolumn{2}{|c|}{ Forecrop harvest date (II) } & \multirow[b]{2}{*}{ Means } \\
\hline & \begin{tabular}{|c|}
$\begin{array}{c}\text { Stage of narrow-leafed } \\
\text { lupine flowering }\end{array}$ \\
\end{tabular} & $\begin{array}{c}\text { Stage of narrow-leafed } \\
\text { lupine flat green pod }\end{array}$ & \\
\hline $\begin{array}{l}\text { Narrow-leafed lupine - pure stand } \\
100 \%\end{array}$ & $4.86 \mathrm{a}^{*}$ & $5.78 \mathrm{a}$ & $5.32 \mathrm{~A}$ \\
\hline Spring rye - pure stand $100 \%$ & $5.12 \mathrm{a}$ & $6.84 b$ & $5.98 \mathrm{~B}$ \\
\hline $\begin{array}{c}\text { Narrow-leafed lupine } 75 \%+\text { spring } \\
\text { rye } 25 \%\end{array}$ & $4.93 \mathrm{a}$ & $5.87 \mathrm{a}$ & $5.40 \mathrm{AB}$ \\
\hline $\begin{array}{c}\text { Narrow-leafed lupine } 50 \%+\text { spring } \\
\text { rye } 50 \%\end{array}$ & $5.03 \mathrm{a}$ & $6.42 \mathrm{ab}$ & $5.73 \mathrm{AB}$ \\
\hline $\begin{array}{c}\text { Narrow-leafed lupine } 25 \%+\text { spring } \\
\text { rye } 75 \%\end{array}$ & $5.09 \mathrm{a}$ & $6.69 \mathrm{~b}$ & $5.89 \mathrm{AB}$ \\
\hline Means & $5.01 \mathrm{~A}$ & $6.32 \mathrm{~B}$ & - \\
\hline ANOVA & \multicolumn{2}{|c|}{ P-value } & $\mathrm{HSD}_{0.05}$ \\
\hline Forecrop - mixtures (I) & \multicolumn{2}{|c|}{$<0.001$} & 0.61 \\
\hline Forecrop harvest date (II) & \multicolumn{2}{|c|}{$<0.001$} & 0.28 \\
\hline Interaction: IxII & \multicolumn{2}{|c|}{$<0.001$} & 0.74 \\
\hline
\end{tabular}

*Values in columns followed by the same small letter and values in rows followed by the same capital letter do not differ significantly at $\mathrm{P}<0.05$ 
The greatest post-harvest residue biomass was supplied by spring rye cultivated in pure stand and mixed with narrow-leafed lupin. The lowest biomass of post-harvest residues was introduced to the soil by narrow-leafed lupin grown in pure stand. Harvest date had a significant influence on the quantity of dry matter of post-harvest residues of narrow-leafed lupin mixed with spring rye, it being higher for mixtures harvested at the stage of narrow-leafed lupin flat green pod compared with the flowering stage. An interaction of the experimental factors resulted in the highest biomass of post-harvest residues being supplied by spring rye and its mixtures with narrow-leafed lupine when they contained $25+75 \%$ and $50+50 \%$ of the respective components.

\section{Nitrogen amount supplied to the soil by incorporating the biomass of post-harvest residues}

Statistical analysis revealed a significant impact of the experimental factors and their interaction on the amount of nitrogen introduced into the soil with the incorporated biomass of the post-harvest residues of narrow-leafed lupin and spring rye (Table 3).

Table 3. Nitrogen amount introduced into soil with incorporated biomass of post-harvest residues (averaged across 2010-2011), $\mathrm{kg} \mathrm{ha}^{-1}$

\begin{tabular}{|c|c|c|c|}
\hline \multirow[b]{2}{*}{ Forecrop - mixtures (I) } & \multicolumn{2}{|c|}{ Forecrop harvest date (II) } & \multirow[b]{2}{*}{ Means } \\
\hline & $\begin{array}{c}\text { Stage of narrow-leafed } \\
\text { lupine flowering }\end{array}$ & $\begin{array}{l}\text { Stage of narrow-leafed } \\
\text { lupine flat green pod }\end{array}$ & \\
\hline $\begin{array}{l}\text { Narrow-leafed lupine - pure stand } \\
100 \%\end{array}$ & $114.7 \mathrm{~d}^{*}$ & $135.2 d$ & 124.9D \\
\hline Spring rye - pure stand $100 \%$ & $68.4 \mathrm{a}$ & $79.8 \mathrm{a}$ & $74.1 \mathrm{~A}$ \\
\hline $\begin{array}{c}\text { Narrow-leafed lupine } 75 \%+\text { spring } \\
\text { rye } 25 \%\end{array}$ & $98.9 c$ & $121.4 \mathrm{dc}$ & $110.2 \mathrm{C}$ \\
\hline $\begin{array}{c}\text { Narrow-leafed lupine } 50 \%+\text { spring } \\
\text { rye } 50 \%\end{array}$ & $92.6 b$ & $109.7 b$ & $101.2 \mathrm{C}$ \\
\hline $\begin{array}{c}\text { Narrow-leafed lupine } 25 \%+\text { spring } \\
\text { rye } 75 \%\end{array}$ & $81.5 b$ & $91.6 b$ & $86.6 \mathrm{~B}$ \\
\hline Means & $91.2 \mathrm{~A}$ & 107.6B & - \\
\hline$A N O V A$ & \multicolumn{2}{|c|}{ P-value } & $\mathrm{HSD}_{0.05}$ \\
\hline Forecrop - mixtures (I) & \multicolumn{2}{|c|}{$<0.001$} & 10.2 \\
\hline Forecrop harvest date (II) & \multicolumn{2}{|c|}{$<0.001$} & 3.8 \\
\hline Interaction: IxII & \multicolumn{2}{|c|}{$<0.001$} & 12.4 \\
\hline
\end{tabular}

*Values in columns followed by the same small letter and values in rows followed by the same capital letter do not differ significantly at $\mathrm{P}<0.05$

The highest nitrogen amount was associated with an incorporation of narrow-leafed lupine post-harvest residues, the quantity of nitrogen accumulated by legume/cereal post-harvest residues being lower. Of the legume/cereal mixtures, the $75+25 \%$ and 50 $+50 \%$ mixtures were the greatest nitrogen contributors. The mixture containing $25+$ $75 \%$ of narrow-leafed lupin and spring rye, respectively,supplied less nitrogen accumulated in its post-harvest residues, it being the lowest in spring rye-post harvest residues. Forecrop harvest date had a significant effect on nitrogen amount introduced into the soil due to an application of post-harvest residues. More nitrogen was supplied 
by the post-harvest residues of narrow-leafed lupin/spring rye mixtures harvested at the stage of narrow-leafed lupin green pod stage, compared with the flowering stage. An interaction between experimental factors was confirmed. Narrow-leafed lupin grown in pure stand and harvested at the flat green pod stage provided more nitrogen in its postharvest residues. Of the mixtures, the post-harvest residues of narrow-leafed lupin/spring rye mixtures containing $75+25 \%$ and $50+50 \%$ of the respective components harvested at the stage of narrow-leafed lupin flat green podintroduced more nitrogen into the soil than the $25+75 \%$ mixture harvested at the same development stage. The post-harvest residues of spring rye harvested at the stage of narrow-leafed lupin flowering and flat green pod were the poorest nitrogen sources.

\section{Winter triticale grain yield}

Winter wheat grain yield was significantly affected by the experimental factors and their interaction (Table 4).

Table 4. Winter triticale grain yield (averaged across 2011-2012), $t \mathrm{ha}^{-1}$

\begin{tabular}{|c|c|c|c|}
\hline \multirow[b]{2}{*}{ Forecrop - mixtures (I) } & \multicolumn{2}{|c|}{ Forecrop harvest date (II) } & \multirow[b]{2}{*}{ Means } \\
\hline & \begin{tabular}{|c|}
$\begin{array}{c}\text { Stage of narrow-leafed } \\
\text { lupine flowering }\end{array}$ \\
\end{tabular} & $\begin{array}{l}\text { Stage of narrow-leafed } \\
\text { lupine flat green pod }\end{array}$ & \\
\hline $\begin{array}{l}\text { Narrow-leafed lupine - pure stand } \\
100 \%\end{array}$ & $9.02 \mathrm{~cd}^{*}$ & $9.83 \mathrm{c}$ & $9.43 \mathrm{CD}$ \\
\hline Spring rye - pure stand $100 \%$ & $6.37 \mathrm{a}$ & $7.08 \mathrm{a}$ & $6.73 \mathrm{~A}$ \\
\hline $\begin{array}{c}\text { Narrow-leafed lupine } 75 \%+\text { spring } \\
\text { rye } 25 \%\end{array}$ & $8.78 \mathrm{c}$ & $9.74 \mathrm{c}$ & $9.26 \mathrm{C}$ \\
\hline $\begin{array}{c}\text { Narrow-leafed lupine } 50 \%+\text { spring } \\
\text { rye } 50 \%\end{array}$ & $9.47 \mathrm{~d}$ & $10.18 \mathrm{c}$ & $9.83 \mathrm{D}$ \\
\hline $\begin{array}{c}\text { Narrow-leafed lupine } 25 \%+\text { spring } \\
\text { rye } 75 \%\end{array}$ & $7.19 b$ & $8.76 b$ & $7.98 \mathrm{~B}$ \\
\hline Means & $8.17 \mathrm{~A}$ & $9.12 \mathrm{~B}$ & - \\
\hline ANOVA & \multicolumn{2}{|c|}{ P-value } & $\mathrm{HSD}_{0.05}$ \\
\hline Forecrop - mixtures (I) & \multicolumn{2}{|c|}{$<0.001$} & 0.48 \\
\hline Forecrop harvest date (II) & \multicolumn{2}{|c|}{$<0.001$} & 0.24 \\
\hline Interaction: IxII & \multicolumn{2}{|c|}{$<0.001$} & 0.55 \\
\hline
\end{tabular}

*Values in columns followed by the same small letter and values in rows followed by the same capital letter do not differ significantly at $\mathrm{P}<0.05$

The highest winter triticale grain yield was obtained following an incorporation of the pos-harvest residues of narrow-leafed lupin grown in pure stand and mixed with spring rye, the respective components being $50+50 \%$. In the remaining plots, grain yield was significantly lower, it being the lowest following an incorporation of spring rye post-harvest residues. Harvest date significantly affected winter triticale grain yield. The yield was higher when narrow-leafed lupin/spring rye mixtures had been harvested at the stage of narrow-leafed lupin flat green pod rather than the flowering stage. An interaction between the experimental factors was confirmed. The highest winter triticale grain yield was producedafter the cereal followedan incorporation of the post-harvest residues of narrow-leafed lupin/spring rye mixture harvested at the stage of narrow- 
leafed lupin flat green pod, and pure-stand narrow-leafed lupin harvested at theaforementioned stage. The lowest yield was produced by cereal following the postharvest residues of spring rye harvested at the stage of narrow-leafed lupin flowering.

\section{0 grain weight of winter triticale}

1000 grain weight of winter triticale was significantly affected by the experimental factors and their interaction (Table 5).

Table 5. Winter triticale 1000 grain weight (averaged across 2011-2012), g

\begin{tabular}{|c|c|c|c|}
\hline \multirow{2}{*}{ Forecrop - mixtures (I) } & \multicolumn{2}{|c|}{ Forecrop harvest date (II) } & \multirow{2}{*}{ Means } \\
\hline & $\begin{array}{c}\text { Stage of narrow-leafed } \\
\text { lupine flowering }\end{array}$ & $\begin{array}{l}\text { Stage of narrow-leafed } \\
\text { lupine flat green pod }\end{array}$ & \\
\hline $\begin{array}{l}\text { Narrow-leafed lupine - pure stand } \\
100 \%\end{array}$ & $46.7 c^{*}$ & $47.9 \mathrm{c}$ & $47.3 \mathrm{C}$ \\
\hline Spring rye - pure stand $100 \%$ & $43.5 \mathrm{a}$ & $44.9 \mathrm{a}$ & $44.2 \mathrm{~A}$ \\
\hline $\begin{array}{c}\text { Narrow-leafed lupine } 75 \%+\text { spring } \\
\text { rye } 25 \%\end{array}$ & $46.8 \mathrm{~cd}$ & $47.2 \mathrm{c}$ & $47.0 \mathrm{C}$ \\
\hline $\begin{array}{c}\text { Narrow-leafed lupine } 50 \%+\text { spring } \\
\text { rye } 50 \%\end{array}$ & $47.5 d$ & $48.9 \mathrm{~d}$ & $48.2 \mathrm{D}$ \\
\hline $\begin{array}{c}\text { Narrow-leafed lupine } 25 \%+\text { spring } \\
\text { rye } 75 \%\end{array}$ & $45.3 b$ & $46.0 \mathrm{~b}$ & $45.7 \mathrm{~B}$ \\
\hline Means & $46.0 \mathrm{~A}$ & $47.0 \mathrm{~B}$ & - \\
\hline ANOVA & \multicolumn{2}{|c|}{ P-value } & $\mathrm{HSD}_{0.05}$ \\
\hline Forecrop - mixtures (I) & \multicolumn{2}{|c|}{$<0.001$} & 0.5 \\
\hline Forecrop harvest date (II) & \multicolumn{2}{|c|}{$<0.001$} & 0.2 \\
\hline Interaction: IxII & \multicolumn{2}{|c|}{$<0.001$} & 0.7 \\
\hline
\end{tabular}

*Values in columns followed by the same small letter and values in rows followed by the same capital letter do not differ significantly at $\mathrm{P}<0.05$

The highest 1000 grain weight was recorded for winter triticale following an incorporation of the post-harvest residues of narrow-leafed lupin/spring rye mixture containing $50+50 \%$ of the respective components. 1000 weight of winter triticale following an incorporation of the post-harvest residues of $75+25 \%$ mixture of narrow-leafed lupine and spring rye was similar but lower than the value recorded for the best experimental unit. In the remaining plots, significantly lower values were recorded, in particular after an incorporation of spring rye post-harvest residues. Harvest date had a significant influence on 1000 grain weight, it being higher after winter triticale followed narrow-leafed lupin/spring rye mixtures harvested at the stage of narrow-leafed lupine flat green pod stage rather than the legume flowering stage. An interaction was confirmed: the highest 1000 grain weight of winter triticale was recorded after an incorporation of the post-harvest residues of the $50+50 \%$ mixture of narrow-leafed lupine and spring rye harvested at the stage of narrow-leafed lupine flat green pod. 1000 grain weight of winter triticale following an incorporation of the postharvest residues of narrow-leafed lupin grown in pure stand and the $75+25 \%$ mixture of narrow-leafed lupin and spring rye harvested at the stage of narrow-leafed lupin flat 
green pod, although significantly lower, remained at a beneficial level. The lowest 1000 grain weight of winter triticale was recorded after an incorporation of the post-harvest residues of spring rye, regardless of the harvest date.

\section{Total nitrogen amount accumulated in winter triticale grain}

Statistical analysis demonstrated a significant effect of the experimental factors and their interaction of the total nitrogen amount accumulated in winter triticale grain (Table 6).

Table 6. Total nitrogen amount accumulated in winter triticale grain (averaged across 2011-2012), $\mathrm{kg} \mathrm{ha}$

\begin{tabular}{|c|c|c|c|}
\hline \multirow[b]{2}{*}{ Forecrop - mixtures (I) } & \multicolumn{2}{|c|}{ Forecrop harvest date (II) } & \multirow[b]{2}{*}{ Means } \\
\hline & \begin{tabular}{|c|}
$\begin{array}{c}\text { Stage of narrow-leafed } \\
\text { lupine flowering }\end{array}$ \\
\end{tabular} & $\begin{array}{l}\text { Stage of narrow-leafed } \\
\text { lupine flat green pod }\end{array}$ & \\
\hline $\begin{array}{l}\text { Narrow-leafed lupine - pure stand } \\
100 \%\end{array}$ & $168.6 c^{*}$ & $181.7 \mathrm{bc}$ & 175.2B \\
\hline Spring rye - pure stand $100 \%$ & $128.9 \mathrm{a}$ & $139.5 \mathrm{a}$ & $134.2 \mathrm{~A}$ \\
\hline $\begin{array}{c}\text { Narrow-leafed lupine } 75 \%+\text { spring } \\
\text { rye } 25 \%\end{array}$ & $169.5 \mathrm{c}$ & $179.3 b$ & $174.4 \mathrm{~B}$ \\
\hline $\begin{array}{c}\text { Narrow-leafed lupine } 50 \%+\text { spring } \\
\text { rye } 50 \%\end{array}$ & $180.6 \mathrm{c}$ & $196.7 \mathrm{c}$ & 188.7B \\
\hline $\begin{array}{c}\text { Narrow-leafed lupine } 25 \%+\text { spring } \\
\text { rye } 75 \%\end{array}$ & $142.4 \mathrm{~b}$ & $148.1 \mathrm{a}$ & $145.3 \mathrm{~A}$ \\
\hline Means & $158.0 \mathrm{~A}$ & $169.1 \mathrm{~B}$ & - \\
\hline$A N O V A$ & \multicolumn{2}{|c|}{ P-value } & $\mathrm{HSD}_{0.05}$ \\
\hline Forecrop - mixtures (I) & \multicolumn{2}{|c|}{$<0.001$} & 14.5 \\
\hline Forecrop harvest date (II) & \multicolumn{2}{|c|}{$<0.001$} & 9.0 \\
\hline Interaction: IxII & \multicolumn{2}{|c|}{$<0.001$} & 16.2 \\
\hline
\end{tabular}

*Values in columns followed by the same small letter and values in rows followed by the same capital letter do not differ significantly at $\mathrm{P}<0.05$

The highest total nitrogen amount was accumulated in the grain of winter triticale following the post-harvest residues of narrow-leafed lupin/spring rye mixture containing $50+50 \%$ of the respective components, and narrow-leafed lupin grown in pure stand. In the remaining units, total nitrogen amount accumulated in winter triticale grain was significantly lower after an incorporation of the post-harvest residues of narrow-leafed lupin/spring rye mixtures, it being the lowest following an incorporation of spring rye post-harvest residues. Harvest date had a significant impact on the amount of total nitrogen accumulated in winter triticale grain. More nitrogen was accumulated in the grain of winter triticale grown after an incorporation of the post-harvest residues of narrow-leafed lupin mixed with spring rye harvested at the stage of narrow-leafed lupin flat green pod rather than the flowering stage. An interaction of the experimental factors was confirmed it indicating that total nitrogen accumulation in grain was the highest when winter triticale was cultivated after the ploughing down of the post-harvest residues of $50+50 \%$ mixture of narrow-leafed lupin and spring rye, and pure-stand narrow-leafed lupin harvested at the stage of flat green pod. The lowest total nitrogen 
amount was accumulated in the grain of winter triticale following an incorporation of the post-harvest residues of spring rye harvested at the stage of narrow-leafed lupin flowering and flat green pod.

\section{Discussion}

The research reported in this work demonstrated that the post-harvest residues of narrow-leafed lupin and its mixtures with spring rye are a valuable source of biological nitrogen for winter triticale. Modern agriculture strives for reducing mineral nitrogen application and replacing it with biological nitrogen which does not pose a threat to the environment (Bergvist, 2003; Hauggard-Nielsen et al., 2012). Also Thorsed et al. (2006) and Arlauskiene and Maiksteniene (2008) reported that, following biological transformation, incorporated biomass becomes a source of nitrogen for the crop plants in the subsequent year. In the experiment reported here, the highest amount of postharvest residues was supplied by spring rye and narrow-leafed lupin/spring rye mixtures containing $25+75 \%$ and $50+50 \%$ of the respective components. Buraczyńska et al. (2011), who cultivated field pea, spring wheat and their mixtures for seed production purposes, found that highest amounts of post-harvest residues were supplied by spring triticale grown in pure stand and mixed with field pea, the respective components being $25+75 \%$. High biomass production by grasses and cereals was also confirmed by Watson et al. (2002), Arlauskiene and Maiksteriene (2008), Nemeikšiene et al. (2010) and Sarunaite et al. (2013). In the present study, the post-harvest residues of narrowleafed lupin grown in pure stand introduced the lowest biomass amount into the soil. Also research by Bergvist (2003) and Panagiotis (2015) confirmed that, compared with cereals or grasses, leguminous plantsupply less biomass, which is due to the fact that their rooting system is not as well developed as that of grasses although narrow-leafed lupin forms a tap root system. In the present experiment, harvest date had a significant effect on the amount of dry matter supplied by the post-harvest residues of narrowleafed lupin/spring rye mixtures. A significantly higher amount of post-harvest biomass was supplied by the legume/cereal mixtures harvested at the stage of narrow-leafed lupine flat green pod compared with the flowering stage. It can be explained by the fact that plants harvested at a more advanced growth stage develop more root matter, which translates into a higher amount of biomass supplied with post-harvest residues.

Post-harvest residues of leguminous plants and their mixtures with cereals are a valuable source of biological nitrogen for the following crops (Buraczyńska et al., 2011). In the present study, the highest nitrogen quantity was supplied to the soil with the post-harvest residues of narrow-leafed lupin, which corresponds with findings reported by Bergvist (2003), Thorsed et al. (2006), Sarunaite et al. (2013) and Panagiotis (2015). It should be stressed that the post-harvest residues of legume/cereal mixtures supply large nitrogen amounts for the following crop (Lemola et al., 2000; Känkänen and Eriksson, 2007; Kramberger et al., 2009; Buraczyńska et al., 2011). In the study discussed here, the highest nitrogen supply was associated with the $75+25 \%$ and $50+50 \%$ mixtures of narrow-leafed lupin and spring rye, it being the lowest for spring rye crop residues, which is due to the fact that non-legumes contain less nitrogen and, as a result, are poorer sources of this element for the following plant. The research by Känkänen and Eriksson (2007) confirms this finding as the authors demonstrated that grasses provided less nitrogen for the crop that followed. In the study reported here, harvest date had a significant influence on the amount of nitrogen introduced into the 
soil with post-harvest residues. More nitrogen was supplied by residues of narrowleafed lupin mixed with spring rye and harvested at the stage of narrow-leafed lupin flat green pod compared with the flowering stage, which can be explained by the fact that plants harvested at an earlier development stage contained more nitrogen but their supply of this element is lower because they develop less biomass in the form of postharvest residues than plants harvester later in the season, the finding corresponding with results reported byMechri et al. (2016).

Studies by Smagacz (2004), Piekarczyk (2010), Prusiński et al. (2016) and Faligowska et al. (2019) demonstrated that the grain yield of winter cereals following leguminous crops was higher compared with cereal forecrops. Triticale is a species which has been recently introduced for cultivation. As a result, there is a paucity of research into the effect of agrotechnological factors, including forecrop, on triticale yield (Noworolnik and Jaśkiewicz, 2018). In the present study, the highest grain yield of winter triticale was recorded after the cereal followed the narrow-leafed lupin/spring rye mixture containing $50+50 \%$ of the respective components, and after pure-stand narrow-leafed lupin. High grain yield was also recorded after an incorporation of the 75 $+25 \%$ mixture of narrow-leafed lupin and spring rye harvested at the stage of narrowleafed lupin flat green pod. Research by Buraczyńska et al. (2011) revealed that the highest winter wheat grain yield was associated with an incorporation of the postharvest residues and straw of spring triticale/filed pea mixture containing $25+75 \%$ of the respective components, as well as field pea post-harvest residues and straw. Also Pszczółkowska et al.(2018) reported a high increase in spring wheat grain yield following leguminous plants. In turn, Känkänen et al. (2001), Känkänen and Erikssen (2007) as well as Nemeikšien et al. (2010) reported thatundersown legumes positively affected cereal grain yield. In the experiment reported here, winter triticale grain yield was the lowest following an incorporation of spring rye post-harvest residues. Piekarczyk (2010) and Buraczyńska et al. (2011) demonstrated that post-harvest residues of cereals grown for grain contributed to a decline in cereal grain yield compared with leguminous residues. Känkänen and Erikssen (2007) as well as Nemeikšien et al. (2010) reported a decline in grain yield when cereal had followed undersown grasses. It may have been due to the fact that leguminous plants and their mixtures with cereals or grasses have a narrower $\mathrm{C}: \mathrm{N}$ ratio compared with cereals or grasses. It contributed to a more rapid decomposition of the incorporated biomass and release of more nitrogen to be used by the following crop which was able to produce a higher yield. In the present study, harvest date of narrow-leafed lupin/spring rye mixtures significantly affected winter triticale grain yield. The yield was higher following an incorporation of the post-harvest residues of narrow-leafed lupine mixed with spring rye and harvested at the stage of flat green pod compared with the flowering stage. This finding can be explained by the fact that post-harvest residues of narrowleafed lupin/spring rye mixtures ploughed down at an earlier development stage undergo more rapid mineralization, and the following crop cannot fullyutilize the nitrogen provided in this way. The element is leached into deeper soil layers and pollutes the soil environment. Better results may be obtained after an incorporation of post-harvest residues of narrow-leafed lupin/spring rye mixtures at a later development stage, that is the stage of narrow-leafed lupine flat green pod.

In the present study, the highest 1000 grain weight of winter triticale was recorded after the cereal followed the $50+50 \%$ mixture of narrow-leafed lupin and spring rye. Good results were also obtained for winter triticale grown after an incorporation of the 
narrow-leafed lupin/spring mixture containing $75+25 \%$ of the respective components. Also research by Buraczyńska et al. (2011) demonstrated that the highest 1000 grain weight of winter wheat, in addition to the greatest grain yield, was produced when the crop had followed a spring triticale/field peat mixture containing $25+75 \%$ of the respective components. It may be explained by the fact that winter cereal growing in good, biological nitrogen-rich soil performs well in terms of grain yield and fill.

In the experiment reported here, winter triticale grain accumulated different amounts of total nitrogen depending on the forecrop. The highest total nitrogen quantity was determined in the grain of winter triticale following the narrow-leafed lupin/spring rye mixture containing $50+50 \%$ of the respective components as well as narrow-leafed lupin grown in pure stand, which corresponds with findings reported by Buraczyńska et al. (2011). These authors obtained the highest nitrogen amounts in the grain of winter wheat following field pea grown for grain, and after spring triticale/field pea mixture containing $25+75 \%$ of the respective components. A positive effect of leguminous plants on nitrogen accumulation in cereal grain has also been reported by Känkänen and Erikssen (2007), Herridge et al. (2008), Nemeikšien et al. (2010) and Hauggard-Nielsen et al. (2012), which was due to the fact that the post-harvest residues of legumes leave a large quantity of nitrogen compared with non-legumes, a great share of this nitrogen being available for the following plant after mineralization. The work reported here demonstrated that the narrow-leafed lupin/spring rye mixture containing $75+25 \%$ of the respective components positively affected nitrogen accumulation in winter triticale grain. The amount of total nitrogen was higher when winter triticale had followed narrow-leafed lupin mixed with spring rye and harvested at the flat green pod stage compared with the flowering stage. The possible explanation is that the post-harvest residues of narrow-leafed lupin/spring rye mixtures accumulated more nitrogen at the legume flat green pod stage than the flowering stage. As a result, the cereal retrieved the nitrogen fixed from the air by legumes thus reducing the risk of nitrogen leaching (Nykänen et al., 2009; Nemeikšiene et al., 2010). Taking the above into account, it seems necessary to continue research on the forecrop effect of post-harvest residues of other legume/cereal mixture combinations in winter cereal production.

Mixture of narrow-leafed lupine with spring rye with $50 \%+50 \%$ components collected in the flat green pod stage is a good forecrop for winter triticale.

\section{Conclusions}

1) The greatest quantity of post-harvest residues was supplied by spring rye and narrow-leafed /spring rye mixtures containing $25+75 \%$ and $50+50 \%$ of the respective components harvested at the stage of narrow-leafed lupin flat green pod, the nitrogen supply being the highest for narrow-leafed lupin harvested at the aforementioned development stage.

2) The highest grain yield was produced by winter triticale cultivated after an incorporation of the post-harvest residues of narrow-leafed lupin/spring rye mixture containing $50+50 \%$ of the respective components and harvested at the stage of legume flat green pod.

3) Grain of winter triticale following an incorporation of the post-harvest residues of narrow-leafed lupin/spring rye mixtures had the highest 1000 grain weight and the greatest nitrogen accumulation, regardless of the date on which the mixtures were harvested. 
4) It is recommended to continue research on the subsequent impact of legumes and cereals on the yield of winter cereals or winter oilseed rape.

\section{REFERENCES}

[1] AOAC (2006): Official methods of analysis ofAOAC International. - 18th edition, Horwitz, W., Latimer Jr., G. (eds.), Publisher: Gaihersburg.

[2] Arlauskiene, A., Maiksteniene, S. (2008): The effects of cover crops and straw on soil mineral nitrogen dynamics and losses from arable land. - AgronomijasVěstis 11: 195201.

[3] Bergvist, G. (2003): Effect of white clover and nitrogen availability on the grain yield of winter wheat in a three-season intercropping system. - Soil Plant Science 53: 97-109.

[4] Buraczyńska, D., Ceglarek, F., Gąsiorowska, B., Zaniewicz-Bajkowska, A., Płaza, A. (2011): Cultivation of wheat following pea and triticale/pea mixtures increases yields and nitrogen content. - Acta Agric. Scan. Ser. B, Soil and Plant Sci. 61: 622-632.

[5] Faligowska, A., Szymańska, G., Panasiewicz, K., Szukala, J., Koziara, W., Ratajczak, K., (2019): The long-term effect of legumes as forecrops on the productivity of rotation (winter rape-winter wheat-winter wheat) with nitrogen fertilization. - Plant, Soil and Env. 65(3): 138-144.

[6] Hauggard-Nielsen, H., Mundus, S., Jensen, E.S. (2012): Grass-clover undersowing affects nitrogen dynamics in a grain legume-cereal arable cropping system. - Field Crops Research 136: 23-31.

[7] Herridge, D.F., Peoples, M.B., Boddey, R.M. (2008): Global inputs of biological nitrogen fixation in agricultural system. - Plant and Soil 311: 1-18.

[8] Jensen, E.S., Hauggaard-Nielsen, H. (2003): How can increased use of biological $\mathrm{N}_{2}$ fixation in agriculture benefit the environment? - Plant and Soil 252: 177-186.

[9] Känkänen, H., Eriksson, C., Räkköläinen, M., Vuorien, M. (2001): Effect of annually repeated undersowing on cereal grain yields. - Agricultural and Food Science in Finland 10: $197-208$.

[10] Känkänen, H., Eriksson, C. (2007): Effects of undersown crops on soil mineral N and grain yield of spring barley. - European Journal of Agronomy 27: 25-34.

[11] Kramberger, B., Gselman, A., Janzekovic, M., Kaligaric, M., Bracko, B. (2009): Effects of cover crops on soil mineral nitrogen and on yield and nitrogen content of maize. European Journal of Agronomy 31: 103-109.

[12] Lemola, R., Turtola, E., Erikson, C. (2000): Undersowing Italian ryegrass diminishes nitrogen leaching from spring barley. - Agric. Food Sci. Finland 9: 201-215.

[13] Mayer, J., Buegger, F., Jensen, E.S.(2003): Residual nitrogen contribution from grain legumes to succeeding wheat and rape and related microbial process. - Plant and Soil 255(2): 541-554.

[14] Mechri, M., Patil, S.B., Saidi, W., Hajri, R., Jarrahi, T., Gharbi, A., Jedidi, N. (2016): Soil organic carbon and nitrogen status under fallow and cereal-legume species in a Tunisian semi-arid conditions. - European Journal of Earth and Environment 3(1): 1-13.

[15] Nemeikšiene, D., Arlauskienne, A., Šlepetiene, A.(2010): Mineral nitrogen content in the soil and winter wheat productivity as influenced by the pre-crop grass species and their management. - Žemdirbyste=Agriculture 97(4): 23-36.

[16] Noworolnik, K., Jaśkiewicz, B.(2018): Wpływ zróżnicowanych warunków glebowych na plonowanie odmian pszenżyta ozimego. - Frag. Agron. 35(1): 62-71.

[17] Nykänen, A., Salo, T., Granstedt, A.(2009): Simulated cereal nitrogen uptake and soil mineral nitrogen after clover-grass leys. - Nutrient Cycling in Agroecosystems 85: 1-15.

[18] Panagiotis, D. (2015): Grain legume effects on soil nitrogen mineralization potential and wheat productivity in Mediterranean environment. - Archives of Agronomy and Soil Science 61(4): 461-473. 
[19] Piekarczyk, M.(2010): Effect of forecrops and nitrogen fertilization on the yield and grain technological quality of winter wheat grown on light soil. - Acta Sci. Pol. Agric. 9(2): 2533.

[20] Prusiński, J., Borowska, M., Kaszkowiak, E., Olszak, G. (2016): The after-effect of chosen Fabaceae forecrops on the yield of grain and protein in winter triticale (Triticosecale sp. Wittmack ex A. Camus 1027) fertilized with mineral nitrogen. - Plant, Soil and Environ. 62(12): 571-576.

[21] Pszczółkowska, A., Okorski, A., Olszewski, J., Fordoński, G. (2018): Effects of prepreceding leguminous crops on yield and chemical composition of winter wheat grain. Plant, Soil and Env. 64(12):592-596.

[22] Sarunaite, L., Kadziuline, Z., Deveikyte, I., Kadziulis, L. (2013): Effect of legume biological nitrogen on cereals yield and soil nitrogen budget in double-cropping system. Journal of Food Agriculture and Environment 11(1): 528-533.

[23] Smagacz, J. (2004): Reakcja wybranych odmian pszenicy ozimej na przedplon. - Biul. IHAR 231: 65-71.

[24] Thorsted, M.D., Olesen, J.E., Weiner, J. (2006): Mechanical control of clover improves nitrogen supply and growth of wheat in winter wheat/white clover intercropping. European Journal of Agronomy 24: 149-155.

[25] Tripolskaja, L., Šidlauskas, G. (2010): The influence of catch crops for green manure and straw on the infiltration of atmospheric precipitation and nitrogen leaching. Žemdirbyste=Agriculture 97(1): 83-92.

[26] Watson, C.A., Atkinson, D., Gosling, P. (2002): Managing soil fertility in organic farming systems. - Soil Use and Management 18: 239-247. 